\title{
Meat consumption and K-ras mutations in sporadic colon and rectal cancer in The Netherlands Cohort Study
}

\author{
M Brink', MP Weijenberg*,', AFPM de Goeij², GMJM Roemen ${ }^{3}$, MHFM Lentjes $^{3}$, AP de Bruïne' ${ }^{2}$, \\ RA Goldbohm ${ }^{4}$ and PA van den Brandt'
}

'Nutrition and Toxicology Research Institute Maastricht (NUTRIM), Department of Epidemiology, Maastricht University, PO Box 616, 6200 MD, Maastricht, The Netherlands; ${ }^{2}$ Research Institute Growth and Development (GROW), Department of Pathology, Maastricht University, PO Box 6I6, 6200 MD, Maastricht, The Netherlands; ${ }^{3}$ NUTRIM, Department of Pathology, Maastricht University, The Netherlands; ${ }^{4}$ TNO Nutrition and Food

Research, Zeist, The Netherlands

\begin{abstract}
Case-cohort analyses were performed on meat and fish consumption in relation to K-ras mutations in 448 colon and I60 rectal cancers that occurred during 7.3 years of follow-up, excluding the first 2.3 years, and 2948 subcohort members of The Netherlands Cohort Study on diet and cancer. Adjusted incidence rate ratios and 95\% confidence intervals were computed for colon and rectal cancer and for K-ras mutation status subgroups. Total fresh meat, most types of fresh meat and fish were not associated with colon or rectal cancer, neither overall nor with K-ras mutation status. However, several weak associations were observed for tumours with a wild-type K-ras, including beef and colon tumours, and an inverse association for pork with colon and rectal tumours; for meat products, an increased association was observed with wild-type K-ras tumours in the colon and possibly with G>A transitions in rectal tumours.
\end{abstract}

British Journal of Cancer (2005) 92, 1310 - 1320. doi: 10.1038/sj.bjc.660249| www.bjcancer.com

(c) 2005 Cancer Research UK

Keywords: meat; colon; rectum; wild-type K-ras

Epidemiological evidence on different types of meat, meat products and fish in relation to colorectal cancer (CRC) risk is not consistent (Giovannucci and Willett, 1994; Potter, 1996; Norat et al, 2002) perhaps, in part, due to the heterogeneity of the colon and rectal cancer end point. Associations may become more apparent when the molecular events involved in colorectal carcinogenesis are taken into account.

Most colorectal tumours develop from small adenomatous polyps through a well-defined sequence of morphological changes (Hill et al, 1978), associated with the acquisition of somatic mutations (Vogelstein et al, 1988; Fearon and Vogelstein, 1990). A genetic alteration that occurs in adenomas (10\%) as well as in carcinomas $(40 \%)$ of the colorectum is the oncogenic activation of the K-ras gene by mutations. Activating mutations are mainly found in codons 12 and 13 (Bos et al, 1987; Vogelstein et al, 1988; Breivik et al, 1994; Brink et al, 2003); those most frequently observed are the $\mathrm{G}>\mathrm{A}$ transitions, $\mathrm{G}>\mathrm{T}$ and $\mathrm{G}>\mathrm{C}$ transversions (Urosevic et al, 1993; Martinez-Garza et al, 1999; Brink et al, 2003).

The link between several types of fresh meat, meat products and fish, and the pattern of K-ras mutations in CRC is not clear. To date, only a few case-control and case-case studies have been conducted on the association between dietary factors and $\mathrm{K}$-ras mutation status (Bautista et al, 1997; Martinez et al, 1999; Voskuil,

*Correspondence: Dr MP Weijenberg, Nutrition and Toxicology Research Institute Maastricht (NUTRIM), Department of Epidemiology, Maastricht University, PO Box 616, 6200 MD, Maastricht, The Netherlands; E-mail: mp.weijenberg@epid.unimaas.nl

Received 3 November 2004; revised 31 January 2005; accepted 2 February 2005
1999; Kampman et al, 2000; O'Brien et al, 2000; Slattery et al, 2000). Four studies reported on different types of meat consumption (Martinez et al, 1999; Kampman et al, 2000; O'Brien et al, 2000; Slattery et al, 2000).

It has been suggested that $\mathrm{N}$-nitroso compounds, present in processed meat or endogenously formed (Bingham et al, 1996), may induce $\mathrm{G}>\mathrm{A}$ transitions at the second base of codon 12 or 13 of the K-ras gene in the human colon (Hughes et al, 2001). Hightemperature cooking of meat proteins generates heterocyclic aromatic amines (HAA), whereas the process of grilling and smoking of meat generates polycyclic aromatic hydrocarbons $(\mathrm{PAH})$ as a result of fat dropping on open flames. HAA-DNAadducts can cause transitions and transversions, whereas PAHs could induce $\mathrm{G}>\mathrm{T}$ transversions in the $\mathrm{K}$-ras gene. Results from relevant animal experiments, however, are not consistent (Vineis and McMichael, 1996).

Since high meat and fish consumption could contribute to acquired genetic alterations in the $K$-ras oncogene in colon and rectal tumours, these dietary items have been studied in relation to the risk of specific point mutations in the $K$-ras oncogene in colorectal cancer patients studied within The Netherlands Cohort Study on diet and cancer (NLCS).

\section{MATERIALS AND METHODS}

\section{Study population}

The study subjects are incident colon and rectal cancer cases and subcohort members from the NLCS, which has been described in detail elsewhere (Van den Brandt et al, 1990a). Briefly, the cohort 
study was initiated in 1986 and includes 58279 men and 62573 women, aged 55-69 years at baseline, who originated from 204 Dutch municipalities with computerised population registries. A self-administered questionnaire on diet and other risk factors for cancer was completed at baseline. The entire cohort is being monitored for cancer occurrence by annual record linkage to The Netherlands Cancer Registry (NCR, nine cancer registries in The Netherlands) and to PALGA, a nationwide network and registry of histo- and cytopathology (www.palga.nl) (Van den Brandt et al, 1990b). In the municipalities included in the NLCS, the NCR and PALGA, together, have nearly $100 \%$ coverage since the start of the study (Schouten et al, 1993, 1994; Van der Sanden et al, 1995). PALGA also provides necessary information on the identification of the pathology laboratory location of the storage of paraffinembedded blocks of the eligible CRC patients. Accumulation of person-time in the cohort has been estimated through biennial vital status follow-up of a subcohort of 3500 men and women who were randomly selected after baseline exposure measurement. Cases with prevalent cancer other than nonmelanoma skin cancer were excluded from the subcohort, which left 3346 men and women for analyses.

The first 2.3 years of follow-up were excluded due to incomplete coverage of PALGA alone in some of the municipalities included in the NLCS. Within this period, 83 subcohort members were either deceased or diagnosed with cancer other than nonmelanoma skin cancer, leaving 3263 men and women for analysis. From 1989 till 1994, 929 incident cases with histologically confirmed CRC were observed of whom 819 could also be linked to a PALGA report of the lesion. The PALGA database was used to identify and locate tumour tissue in Dutch pathology laboratories. Colorectal cancer was classified according to site as follows: colon, that is, cecum through sigmoid colon (ICD-O-1 codes: 153.0, 153.1, 153.2, 153.3, $153.4,153.5,153.6,153.7,153.8,153.9$ ), rectosigmoid (ICD-O-1 code 154.0) and rectum (ICD-O-1 code 154.1). Information about age at baseline, sex and family history of CRC (at baseline) was retrieved from the NLCS database.

\section{Tissue samples}

This study is based on data of gene mutation analysis from CRC patients, described in detail elsewhere (Brink et al, 2003). Briefly, tumour material of all CRC patients was collected after approval by the Medical Ethics Committees of Maastricht University, the NCR and PALGA. Subsequently, all pathology laboratories in The Netherlands agreed to make relevant tissue samples available upon request from PALGA. Tissue samples of the 819 cases were distributed among 54 pathology laboratories throughout The Netherlands. Tumour tissue collection started in August 1999 and was completed in December 2001. The loss to follow-up of tissue samples of cases amounted to 5\%. Tissue samples from nine patients registered in one pathology laboratory could not be retrieved due to administrative inconsistencies, leaving 810 tissue samples for collection. For 34 cases, paraffin-embedded material was not available in the archives of pathology laboratories, leaving 776 cases for the determination of the K-ras mutation status. For 39 cases (5\%), the $K$-ras mutation status could not be determined, that is, for 20 cases only normal colonic mucosa was available, 10 cases were revised with an benign adenoma (AdB) instead of an adenocarcinoma, for six cases the yield of DNA was not sufficient to determine $K$-ras mutation status and for three cases the available tissue did not include malignant CRC tissue. Finally, tumour material from 737 incident colorectal adenocarcinoma cases was available of whom 476 were colon cancer cases, 85 were rectosigmoid cancer cases and 176 were rectal cancer cases. Statistical analyses were performed separately for colon and rectal cancer as differences in the aetiology of colon and rectal cancer have been reported (Potter, 1996). Since the rectosigmoid can be considered as a clinically applied term rather than an anatomically defined transitional zone between the colon and rectum, patients with a rectosigmoid tumour were excluded from data-analyses. Moreover, the number of patients with a rectosigmoid tumour was too small for adequate stratified analyses (Brink et al, 2003).

\section{Detection of $K$-ras mutations}

Mutation analysis of the exon 1 fragment of the K-ras oncogene, spanning codons 8-29, was performed on archival colorectal adenocarcinoma specimens of all 737 CRC patients using macrodissection, nested polymerase chain reaction (PCR) and direct sequencing of purified fragments, which has been described in detail elsewhere (Brink et al, 2003). The method of mutation detection was validated by the confirmation of reported $\mathrm{K}$-ras status in CRC cell lines and a good correlation between freshfrozen and routinely fixed, paraffin-embedded tissue. The detection limit was 5\% mutated DNA. Duplicate analyses revealed a good reproducibility (88\%) (Brink et al, 2003). Two observers (GR and $\mathrm{ML}$ ) independently performed evaluation of mutation analysis and data-entry.

\section{The food frequency questionnaire}

The dietary section of the questionnaire covered a 150-item semiquantitative food frequency, which concentrated on habitual consumption of food and beverages during the year preceding the start of the study. Daily mean nutrient intakes were calculated using the computerised Dutch food composition table (Dutch food composition table (NEVO table, 1986)), by multiplying frequencies and portion sizes of all food items with their tabulated nutrient contents. The questionnaire was validated against a 9-day diet record (Goldbohm et al, 1994a). The Spearman correlation coefficients for total fresh meat, meat products and fish were 0.46, 0.54 and 0.53, respectively (Goldbohm et al, 1994a). Questionnaire data were key-entered twice and processed for all incident cases in the cohort and for all subcohort members in a manner blinded with respect to case/subcohort status. This was carried out in order to minimise observer bias in coding and interpretation of the data.

For 257 subjects (28 incident colon adenocarcinoma cases, 16 incident rectal adenocarcinoma cases and 215 subcohort members; two subcohort members were also colon or rectal cancer cases), dietary data were incomplete or inconsistent, and they were excluded from the analyses. These subjects either (1) left 60 or more (out of 150) questionnaire items blank and ate fewer than 35 items at least once per month and/or (2) left one or more item blocks (groups of items, i.e. beverages) blank. Additional details are given elsewhere (Goldbohm et al, 1994a). Hence, 448 colon and 160 rectal cases and 3048 subcohort members were available for data-analyses.

The food frequency questionnaire contained 14 items on the consumption of meat with the main (hot) meal (mainly fresh meat, including chicken), five items on the consumption of meat products, which are used as sandwich filling and three items on fish consumption. For the serving size of total fresh meat, a question was included on the quantity of meat usually purchased (per person, per meal). Fresh meat is defined as meat that has not undergone some form of preservation, that is, smoking, fermentation and/or treatment with nitrate and/or nitrite salt ('curing') and which includes beef, pork, minced meat, chicken, liver and other meat (i.e. sausages). Coding of fresh meat items was based on raw weight to take into account the amount of fat originally present in the meat but ultimately ending up into the gravy, which is usually consumed as well. Meat products are defined as meat items that have undergone some form of preservation (mostly cured, sometimes also smoked or fermented). For chicken and fish, standard serving sizes were used. Meat items 
included in the questionnaire were converted into mean daily consumption in grams.

Quartiles of the consumption of total fresh meat, beef, pork, liver, minced meat, other meat and meat products were computed for men and women separately, based on the distribution of subcohort members as described in detail later. For chicken and fish, groups were classified into a nonuser and three user categories $\left(5.3-13.2,13.2-22.8\right.$ and $\geqslant 22.8 \mathrm{~g} \mathrm{day}^{-1}$ for chicken and $0-10,10-20$ and $\geqslant 20 \mathrm{~g} \mathrm{day}^{-1}$ for fish) and this classification was used for both men and women.

Daily intake of dietary fibre $\left(\mathrm{g} \mathrm{day}^{-1}\right)$, alcohol $\left(\mathrm{g} \mathrm{day}^{-1}\right)$, fruit $\left(\right.$ g day $\left.^{-1}\right)$, vegetables $\left(\mathrm{g} \mathrm{day}^{-1}\right)$ and total energy $\left(\mathrm{kcal} \mathrm{day}^{-1}\right)$ and age at baseline (years), sex (men/women), Quetelet Index (QI; $\left.\mathrm{kg} \mathrm{m}^{-2}\right)$, physical activity $\left(<30 \mathrm{~min}^{-1 a y}{ }^{-1}, 30-60 \mathrm{~min} \mathrm{day}^{-1}, 60-\right.$ $90 \mathrm{~min} \mathrm{day}^{-1},>90 \mathrm{~min} \mathrm{day}^{-1}$ ), family history of CRC (yes/no) and smoking status (never/ex/current) were regarded as potential confounders.

\section{Statistical analysis}

The overall frequency of $K$-ras mutations as well as the type of mutation were computed for all colon and rectal cancer cases as described elsewhere (Brink et al, 2003). Mean values of the continuous variables age at baseline (years), consumption of total fresh meat, beef, pork, minced meat, chicken, liver, other meat, meat products, fish, dietary fibre, alcohol, fruit, vegetables, total energy and QI were evaluated for subcohort members and colon and rectal cancer cases with wild-type and mutated K-ras gene. Distributions of the categorical variables sex, family history of CRC, smoking status and physical activity were evaluated for subcohort members and colon and rectal cancer patients with wild-type and mutated $K$-ras gene and tested for differences between patient groups with the $\chi^{2}$-test. Differences in mean values of the continuous variables between patients with wild-type and mutated $K$-ras gene were tested with the Student $t$-test or the Mann-Whitney $U$-test if the variables were not normally distributed. The statistical software package SPSS (version 9) was used for these analyses.

Incidence rate ratios (RRs) and corresponding 95\% confidence intervals (CI) were estimated for colon and rectal cancer cases with wild-type or mutated $K$-ras gene tumours. RRs were computed using Cox regression models with the STATA statistical software package (intercooled STATA, version 7) according to consumption of quartiles or categories and one standard deviation (s.d.) of increase in fresh meat, meat products and fish, all based on the distribution in the subcohort. The lowest quartile or category of consumption was regarded as the reference category. The personyears at risk, estimated from the subcohort, were used in the denominator of the incidence rates (Van den Brandt et al, 1990a). Standard errors were estimated using the robust Huber-White sandwich estimator to account for additional variance introduced by sampling from the cohort. This method is equivalent to the variance-covariance estimator as presented by Barlow et al (1999). The proportional hazards assumption was tested using the scaled Schoenfeld residuals (Schoenfeld, 1982). Those variables that were found to contribute substantially $(P<0.10)$ to the multivariate model for colon and/or rectal cancer (age, sex, QI, smoking, energy intake and family history of CRC) were included as covariates in all multivariate analyses. Interactions between total fresh meat, meat products and fish consumption on one hand and sex on the other hand were tested for colon and rectal cancer separately and not found to be statistically significant. Therefore, results for men and women are presented together. Finally, age at baseline, sex, family history of CRC, smoking status, QI and the intake of energy were confounders for either one or both of the models, that is, with colon or rectal cancer cases, and were therefore included as covariates for all models to be tested. Since 100 subcohort members had missing values for QI, results in the tables (except for Table 1) concern 2948 subcohort members. For each analysis, linear trends were evaluated with the Wald test of the regression coefficient estimate by fitting ordinal exposure variables (quartiles/categories of consumption) as continuous terms.

\section{RESULTS}

The overall frequency and spectrum of mutations in the $K$-ras gene have been presented in detail elsewhere (Brink et al, 2003). In brief, a total of 227 mutations were found in 218 (36\%) out of 608 colon and rectal cancer patients. The most frequently observed mutations are the $\mathrm{G}>\mathrm{A}$ transitions (54\%), $\mathrm{G}>\mathrm{T}$ transversions $(33 \%)$ and $\mathrm{G}>\mathrm{C}$ transversions (7\%). The observed frequencies of the mutations in this series of patients are similar to the frequencies of the $737 \mathrm{CRC}$ cases, including the rectosigmoid cancer cases, for whom $K$-ras mutation status was determined (Brink et al, 2003).

Table 1 shows the baseline characteristics of the study population. Colon and rectal cancer cases were more often men, were older, more frequently reported a family history of CRC, had a higher daily alcohol intake and were less frequently never smokers as compared to the subcohort. Colon cancer cases with a $K$-ras mutation in their tumour had a lower daily consumption of meat products, a higher intake of dietary fibres and were significantly older than colon cancer cases with a wild-type $K$-ras tumour ( $P$-values $0.02,0.02$ and 0.006 , respectively). There were no statistically significant differences between colon cancer cases with and without a $K$-ras mutation in their tumour in dietary consumption of total fresh meat, beef, pork, minced meat, liver, chicken, other meat, fish and other factors presented in Table 1. Rectal cancer cases with a $\mathrm{K}$-ras mutation in their tumour had a lower daily consumption of minced meat, a higher daily consumption of pork and were less frequently men than rectal cancer cases with a wild-type $K$-ras gene in their tumour ( $P$-values $0.03,0.06$ and 0.03 , respectively). No statistically significant differences were observed between rectal cancer cases with and without a $K$-ras mutation in their tumours for other factors presented in Table 1.

Associations between the consumption of total fresh meat, different types of fresh meat, that is, beef, pork, minced meat, liver, chicken and other meat, meat products and fish, and the risk of colon or rectal cancer are presented in Table 2. Relative ratios and $95 \%$ CI for colon and rectal cancer were presented after adjustment for age and sex and after adjustment for age, sex, smoking QI, energy intake and family history of CRC. The age-and-sex adjusted $\mathrm{RR}$ and the multivariate RR were similar. Frequent consumption of total fresh meat, minced meat, liver, chicken, other meat, meat products and fish was not significantly associated with the risk of colon or rectal cancer (Table 2). A high intake of beef was borderline positively associated with the risk of colon cancer (RR for highest $v s$ lowest quartile of consumption 1.28 , 95\% CI $0.96-$ $\left.1.72 ; P_{\text {trend }} 0.06\right)$. There was no association between beef and rectal cancer risk. A high consumption of pork was, however, borderline inversely associated with the risk of colon cancer (RR for highest $v s$ lowest quartile of consumption $0.77,95 \%$ CI $0.57-1.04 ; P_{\text {trend }}$ 0.07 ) and rectal cancer (RR for highest $v s$ lowest quartile of consumption $0.70,95 \%$ CI $0.43-1.13 ; P_{\text {trend }} 0.09$ ).

Associations of total fresh meat, beef, pork, minced meat, liver, chicken, other meat, and meat products and fish with wild-type or mutated $K$-ras gene in colon or rectal tumours are presented in Table 3. Results will first be presented for tumours with a wild-type $K$-ras gene. No clear associations were observed for the highest $v s$ the lowest consumption of total fresh meat, minced meat, liver, chicken, other meat and fish and colon and rectal tumours with a wild-type $K$-ras gene. A nonsignificant, increased association was observed between beef and wild-type $K$-ras colon tumours (RR for highest $v s$ lowest quartile of consumption 1.36, 95\% CI 0.96-1.93; 
Table I Meat variables and other characteristics (mean \pm s.d.) of the study population at baseline

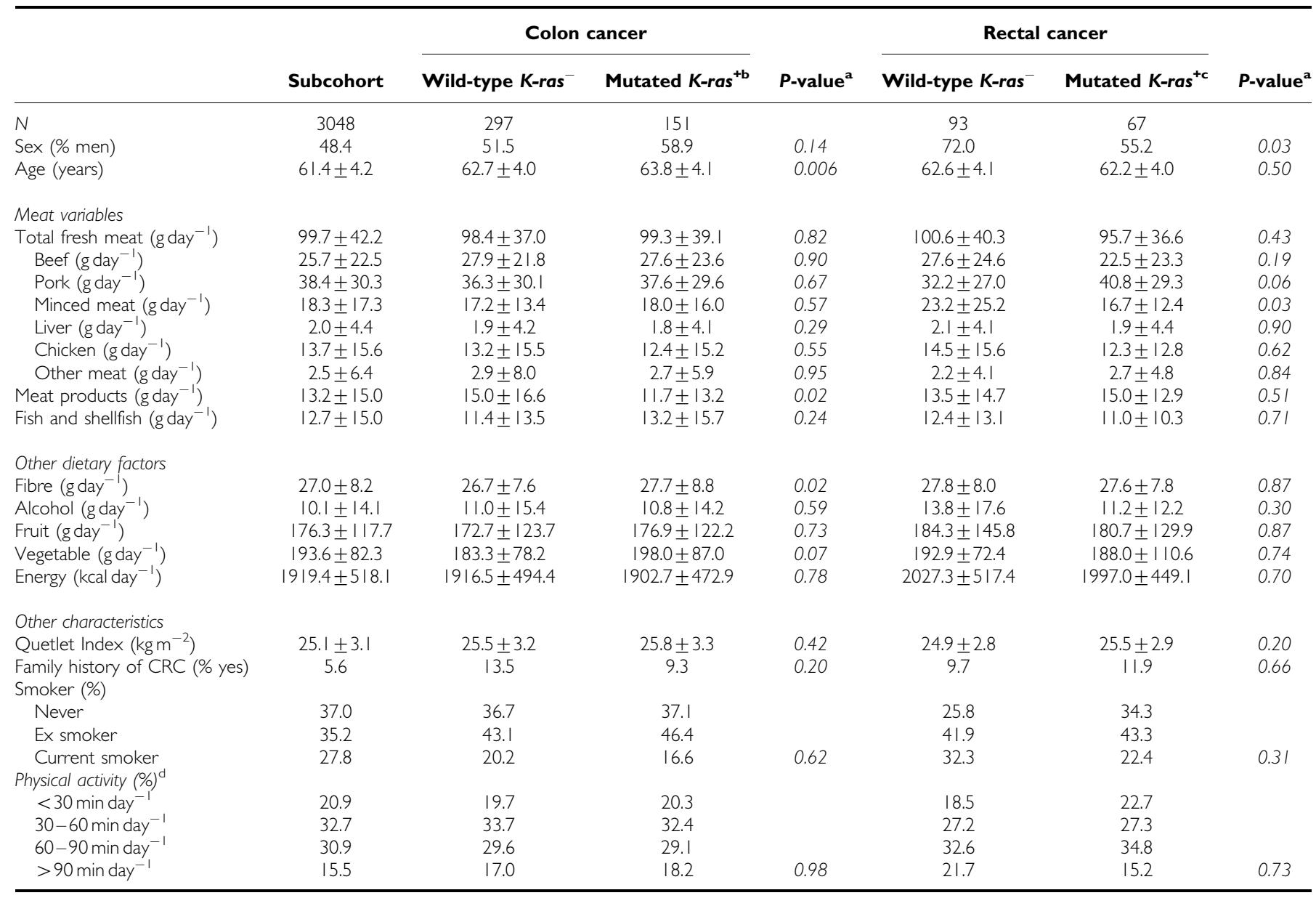

${ }^{a}$ Comparing cases with at least one K-ras mutation to cases without a K-ras mutation. ${ }^{\text {b }}$ ix out of 15 I colon cancer cases had more than one K-ras mutation. ${ }^{\mathrm{c}}$ Three out of 67 rectal cancer cases had more than one K-ras mutation. ${ }^{\mathrm{d}}$ For $4 \mathrm{I}$ subcohort members and nine colorectal cancer cases, information on physical activity was not available.

$P_{\text {trend }}$ 0.08). No association was observed for beef and rectal tumours with a wild-type $K$-ras gene. On the other hand, a high consumption of pork was inversely associated with wild-type $K$-ras colon and rectal tumours (RR for highest $v s$ lowest quartile of consumption $0.72,95 \%$ CI $0.51-1.02 ; P_{\text {trend }} 0.05$ and $0.50,95 \%$ CI $0.26-0.93 ; P_{\text {trend }} 0.01$, respectively). A high consumption of meat products showed a significant increased association with colon tumours with a wild-type $K$-ras gene (RR for highest $v s$ lowest quartile of intake $1.42,95 \%$ CI $\left.1.00-2.03 ; P_{\text {trend }} 0.03\right)$. No clear association was found for high consumption of meat products and rectal tumours with a wild-type $K$-ras gene. Regarding colon and rectal tumours that harbour a $K$-ras mutation, no clear associations were observed between highest $v s$ lowest quartile of consumption of different types of fresh meat, meat products and fish.

Subgroup analyses were performed to evaluate the associations between total fresh meat, different types of fresh meat, meat products and fish, and specific types of $K$-ras point mutations ( $\mathrm{G}>\mathrm{A}$ transitions and $\mathrm{G}>\mathrm{T}$ or $\mathrm{G}>\mathrm{C}$ transversions) in colon and rectal tumours (Table 4). Results will first be presented for tumours with a G > A transition in the K-ras gene. Total fresh meat consumption was not associated with $\mathrm{G}>\mathrm{A}$ transitions in the colon tumours, but an inverse association with $\mathrm{G}>\mathrm{A}$ transitions in the rectal tumours was observed. However, none of the specific types of fresh meat, that is, beef, pork, minced meat, liver, chicken, other meat, nor fish were associated with the risk of $G>A$ transitions in both colon and rectal tumours. For meat products, a borderline significant trend with increased risk of rectal tumours harbouring $\mathrm{G}>\mathrm{A}$ transitions was observed ( $\mathrm{RR}$ for highest $v s$ lowest quartile of intake $2.37,95 \%$ CI $\left.0.75-7.51 ; P_{\text {trend }} 0.07\right)$. Regarding $\mathrm{G}>\mathrm{T}$ or $\mathrm{G}>\mathrm{C}$ transversions in colon and rectal tumours, no clear associations were observed for total fresh meat, the different types of fresh meat, meat products and fish.

\section{DISCUSSION}

In this large cohort study with 448 incident colon and 160 incident rectal cancer patients, no associations were observed between total fresh meat and fish, and the risk of colon or rectal cancer, either overall or after $K$-ras mutation status was taken into account. This was also observed for specific types of fresh meat. However, several weak associations were observed regarding tumours harbouring a wild-type $K$-ras gene. An increased association for high consumption of beef and an inverse association for high consumption of pork, and the risk of colon tumours were observed. In addition, consumption of pork was inversely associated with rectal tumours with a wild-type $K$-ras gene. For meat products, an increased association was observed with wild-type K-ras tumours in the colon and a nonsignificant positive association with $\mathrm{G}>\mathrm{A}$ transitions in the K-ras gene in rectal tumours.

Earlier results on meat and CRC in the NLCS, based on 3.3 years of follow-up, showed no association for high consumption of total fresh meat and fish and colon cancer risk in men and women. A positive association for both men and women was observed for 
Table 2 Incidence rate ratios (RRs) and 95\% confidence intervals $(\mathrm{Cl})$ for colon $(N=448)$ and rectal $(N=160)$ cancer patients overall according to the intake of total fresh meat, meat products and fish

Quartile/category of intake

\begin{tabular}{|c|c|c|c|c|c|c|c|}
\hline Exposure & & $I^{\mathbf{a}}$ & 2 & 3 & 4 & $P$ for trend & $\begin{array}{l}\text { RR }(95 \% \mathrm{Cl}) \text { for one } \\
\text { s.d. increase in intake }\end{array}$ \\
\hline \multicolumn{8}{|l|}{ Total fresh meat } \\
\hline Median intake $\left(\mathrm{g} \mathrm{day}^{-1}\right)$ & $\begin{array}{l}\text { Men } \\
\text { Women }\end{array}$ & $\begin{array}{l}61 \\
50.7\end{array}$ & $\begin{array}{c}91 \\
80.3\end{array}$ & $\begin{array}{l}110.7 \\
103.4\end{array}$ & $\begin{array}{l}150.8 \\
139.2\end{array}$ & & \\
\hline \multirow{2}{*}{ Cases } & Colon & 109 & 112 & 123 & 104 & & \\
\hline & Rectum & 40 & 48 & 40 & 32 & & \\
\hline \multirow{2}{*}{$\begin{array}{l}\text { Person-years } \\
\text { RR }(95 \% \mathrm{Cl})^{c}\end{array}$} & & 3661 & 3701 & 3660 & 3715 & & \\
\hline & Colon & I & $1.03(0.77-1.37)$ & $1.16(0.88-1.54)$ & $0.99(0.74-1.33)$ & 0.8 & $0.97(0.89-1.07)$ \\
\hline & Rectum & i & $1.11(0.7 \mid-1.73)$ & $0.93(0.59-1.47)$ & $0.72(0.44-1.19)$ & 0.14 & $0.89(0.76-1.05)$ \\
\hline \multicolumn{8}{|l|}{ Beef } \\
\hline \multirow[t]{2}{*}{ Median intake $\left(\mathrm{g} \mathrm{day}^{-1}\right)$} & Men & 4.1 & 16.1 & 30 & 51.4 & & \\
\hline & Women & 3 & 14 & 25.5 & 46.9 & & \\
\hline \multirow{2}{*}{ Cases } & Colon & 100 & 98 & 108 & 142 & & \\
\hline & Rectum & 39 & 49 & 32 & 40 & & \\
\hline \multicolumn{8}{|l|}{ Pork } \\
\hline \multirow[t]{2}{*}{ Median intake $\left(\mathrm{g} \mathrm{day}^{-1}\right)$} & Men & 7.9 & 28 & 44.3 & 76 & & \\
\hline & Women & 5 & 22.5 & 40.1 & 66.2 & & \\
\hline \multirow[t]{2}{*}{ Cases } & Colon & 121 & 120 & 109 & 98 & & \\
\hline & Rectum & 44 & 46 & 36 & 34 & & \\
\hline & & 3659 & 3658 & 3688 & 3733 & & \\
\hline $\operatorname{RR}(95 \% \mathrm{Cl})^{\mathrm{c}}$ & Colon & I & $1.03(0.78-1.35)$ & $0.94(0.7 \mid-1.24)$ & $0.86(0.76-1.37)$ & 0.24 & $0.96(0.87-1.07)$ \\
\hline & Rectum & । & $1.07(0.70-1.64)$ & $0.84(0.53-1.33)$ & $0.80(0.50-1.28)$ & 0.22 & $0.90(0.76-1.07)$ \\
\hline $\mathrm{RR}(95 \% \mathrm{Cl})^{d}$ & Colon & । & $0.98(0.74-1.30)$ & $0.90(0.67-1.20)$ & $0.77(0.57-1.04)$ & 0.07 & $0.93(0.83-1.04)$ \\
\hline & Rectum & I & $1.01(0.66-1.56)$ & $0.81(0.51-1.28)$ & $0.70(0.43-1.13)$ & 0.09 & $0.87(0.72-1.03)$ \\
\hline Minced meat & & & & & & & \\
\hline Median intake $\left(\mathrm{g}\right.$ day $\left.^{-1}\right)$ & Men & 3.2 & 11.5 & 21 & 37.8 & & \\
\hline Liver & & & & & & & \\
\hline Median intake $\left(\sigma_{\text {day }}{ }^{-1}\right)$ & Men & 0 & 4.1 & & & & \\
\hline & Women & 0 & 3.7 & & & & \\
\hline Cases & Colon & 295 & 153 & & & & \\
\hline & Rectum & 99 & 61 & & & & \\
\hline Person-years & & 9589 & 5148 & & & & \\
\hline $\operatorname{RR}(95 \% \mathrm{Cl})^{c}$ & Colon & । & $1.02(0.83-1.26)$ & & & 0.84 & $1.00(0.91-1.11)$ \\
\hline & Rectum & I & $1.16(0.83-1.62)$ & & & 0.38 & $1.02(0.88-1.18)$ \\
\hline $\operatorname{RR}(95 \% \mathrm{Cl})^{d}$ & Colon & i & $1.04(0.84-1.29)$ & & & 0.71 & $1.02(0.92-1.12)$ \\
\hline & Rectum & i & $1.11(0.79-1.57)$ & & & 0.54 & $1.02(0.88-1.18)$ \\
\hline Chicken & & & & & & & \\
\hline Median intake $\left(\mathrm{g} \mathrm{day}^{-1}\right)$ & Men/women & 0 & 5.3 & 13.2 & 22.8 & & \\
\hline Cases & Colon & 125 & 101 & 98 & 124 & & \\
\hline & Rectum & 35 & 44 & 33 & 48 & & \\
\hline Person-years & & 3457 & 3564 & 3616 & 4100 & & \\
\hline $\operatorname{RR}(95 \% \mathrm{Cl})^{c}$ & Colon & । & $0.81(0.61-1.07)$ & $0.78(0.58-1.04)$ & $0.86(0.66-1.13)$ & 0.3 & $0.96(0.86-1.07)$ \\
\hline & Rectum & I & $1.26(0.80-2.00)$ & $0.92(0.56-1.50)$ & $1.18(0.76-1.86)$ & 0.77 & $1.00(0.86-1.16)$ \\
\hline $\operatorname{RR}(95 \% \mathrm{Cl})^{\mathrm{d}}$ & Colon & i & $0.85(0.63-1.14)$ & $0.81(0.60-1.08)$ & $0.87(0.66-1.15)$ & 0.34 & $0.95(0.85-1.07)$ \\
\hline & Rectum & I & $1.26(0.79-2.03)$ & $0.94(0.57-1.55)$ & $1.12(0.70-1.79)$ & 0.96 & $0.98(0.83-1.14)$ \\
\hline Other meat & & & & & & & \\
\hline Median intake $\left(\mathrm{g}\right.$ day $\left.^{-1}\right)$ & Men & 0 & 6.6 & & & & \\
\hline & Women & 0 & 7 & & & & \\
\hline
\end{tabular}


Quartile/category of intake

\begin{tabular}{|c|c|c|c|c|c|c|c|}
\hline Exposure & & & & & & $P$ for trend & $\begin{array}{l}\text { RR }(95 \% \mathrm{Cl}) \text { for one } \\
\text { s.d. increase in intake }\end{array}$ \\
\hline Cases & Colon & $3 / 3$ & 135 & & & & \\
\hline \multirow{3}{*}{$\operatorname{RR}(95 \% \mathrm{Cl})^{c}$} & & 10421 & 4316 & & & & \\
\hline & Colon & 1 & $1.13(0.91-1.41)$ & & & 0.25 & $1.05(0.96-1.15)$ \\
\hline & Rectum & 1 & $1.29(0.91-1.81)$ & & & 0.15 & $0.98(0.86-1.11)$ \\
\hline $\operatorname{RR}(95 \% \mathrm{Cl})^{\mathrm{d}}$ & Colon & I & $1.16(0.92-1.46)$ & & & 0.2 & $1.08(0.98-1.18)$ \\
\hline \multicolumn{8}{|l|}{ Meat products ${ }^{\mathrm{e}}$} \\
\hline \multirow[t]{2}{*}{ Median intake $\left(\mathrm{g} \mathrm{day}^{-1}\right)$} & Men & 1 & 7.4 & 15.8 & 33.3 & & \\
\hline & Women & 0 & 4.3 & 10.5 & 22.4 & & \\
\hline \multirow[t]{2}{*}{ Cases } & Colon & 113 & 94 & 118 & 123 & & \\
\hline & Rectum & 44 & 30 & 39 & 47 & & \\
\hline Person-years & & 3588 & 3624 & 3794 & 3732 & & \\
\hline $\operatorname{RR}(95 \% \mathrm{Cl})^{c}$ & Colon & I & $0.87(0.65-1.17)$ & $1.06(0.80-1.40)$ & $1.13(0.86-1.49)$ & 0.22 & $1.04(0.95-1.14)$ \\
\hline \multicolumn{8}{|l|}{ Fish } \\
\hline \multirow[t]{2}{*}{ Median intake $\left(\mathrm{g} \mathrm{day}^{-1}\right)$} & Men & 0 & 4.6 & 14.8 & 30.5 & & \\
\hline & Women & 0 & 4.6 & 15.5 & 28.2 & & \\
\hline \multirow[t]{2}{*}{ Cases } & Colon & 123 & 122 & 116 & 87 & & \\
\hline & Rectum & 48 & 33 & 48 & 31 & & \\
\hline \multirow{3}{*}{$\begin{array}{l}\text { Person-years } \\
\text { RR }(95 \% \mathrm{Cl})^{c}\end{array}$} & & 4235 & 3238 & 4444 & 2820 & & \\
\hline & Colon & I & $1.31(1.00-1.73)$ & $0.92(0.70-1.21)$ & $1.05(0.78-1.41)$ & 0.64 & $0.94(0.85-1.04)$ \\
\hline & Rectum & 1 & $0.86(0.54-1.36)$ & $0.93(0.62-1.41)$ & $0.89(0.56-1.42)$ & 0.7 & $0.91(0.79-1.06)$ \\
\hline \multirow{2}{*}{$\operatorname{RR}(95 \% \mathrm{Cl})^{d}$} & Colon & 1 & $1.30(0.97-1.73)$ & $0.82(0.62-1.09)$ & $1.03(0.76-1.40)$ & 0.4 & $0.93(0.83-1.04)$ \\
\hline & Rectum & । & $0.88(0.55-1.43)$ & $0.97(0.64-1.48)$ & $0.94(0.59-1.52)$ & 0.89 & $0.93(0.80-1.08)$ \\
\hline
\end{tabular}

${ }^{a}$ Reference category/quartile of intake. ${ }^{b}$ See for one s.d. of increase based on the intake of the subcohort (Table I). ${ }^{c}$ Rate ratios adjusted for age and sex. ${ }^{d}$ Rate ratios adjusted for

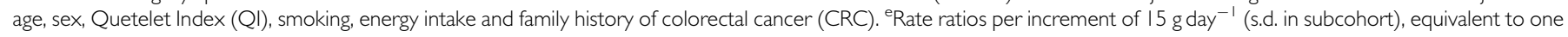
standard sandwich filling.

meat products, which consist mainly of cured meat (Goldbohm et al, 1994b). Rectal cancer was not included in these analyses. These findings were in line with the findings of a meta-analysis conducted by Norat et al (2002). In total, 29 studies were evaluated, including 22 case - control and seven cohort studies for investigating the association between processed meat and CRC. A high consumption of processed meat was found to be associated with a moderate, but significant, increase in CRC risk. In the current study, after 7.3 years of follow-up and with the exclusion of the first 2.3 years, these findings were similar to the earlier results on meat and CRC in the NLCS, that is, neither an association was observed for total fresh meat, different types of fresh meat, nor for fish. However, in the current study, no significant association was observed between meat products and colon or rectal cancer risk overall.

With regard to K-ras mutations, two case-control studies with colon cancer patients, one with 2418 patients and 2410 controls (Slattery et al, 2000), the other with 185 patients (Voskuil, 1999; Kampman et al, 2000), and one cross-sectional case-case study with rectal cancer patients (O'Brien et al, 2000) have previously been conducted and have reported on the association between meat consumption and $\mathrm{K}$-ras mutations. In none of these studies an association between meat consumption and colon or rectal cancer was observed after the $K$-ras gene mutation status was taken into account. The current cohort study on total fresh meat, different types of fresh meat, meat products and fish and specific $K$-ras mutations is, to our knowledge, the only prospective study performed to date. The prospective design of this study and the high completeness of follow-up of cancer incidence and of the subcohort make information and selection bias unlikely. In addition, as a result of the exclusion of the first 2.3 years of follow-up, the chance of information bias due to potential preclinical colorectal cancer is minimal.

Epidemiological studies have indicated that consumption of broiled, fried, barbequed or smoked meats may increase the risk of CRC (Gerhardsson de Verdier et al, 1991; Augustsson et al, 1999; Kampman et al, 1999), although these findings were not consistent. Augustsson et al (1999) observed an inverse association between high intake of HAA and the risk of colon and rectal cancer. However, Gerhardsson de Verdier et al (1991) observed an increased association for total meat intake as well as frequent consumption of brown gravy and a preference for a heavily browned meat surface and the risk of CRC. The relative risks (RR) were higher for rectal than for colon cancer. High-temperature cooking of meat proteins generates HAA, whereas the process of grilling and smoking of meat forms $\mathrm{PAH}$ as a result of fat dropping on open flames. Animal and in vitro studies have shown that HAADNA-adducts can cause transitions and transversions, as observed in the $\mathrm{K}$-ras oncogene. However, results from animal experiments are not entirely consistent (Vineis and McMichael, 1996). In humans, a higher prevalence of $\mathrm{G}>\mathrm{T}$ transversions in the K-ras gene was observed in 37 colorectal tumours from Yugoslavia, which the authors explain as possibly being due to the extensive use of barbequed and smoked meat throughout the year in Yugoslavia (Urosevic et al, 1993). Unfortunately, information on meat preparation, including cooking methods, was not collected at baseline in the current study. Since fresh meat generally needs further preparation, this type of meat may be an important source of these carcinogens. Hence, it is plausible that associations between fresh meat and colon or rectal cancer with specific point 
Table 3 Adjusted $R^{a}$ for colon and rectal cancer patients with a K-ras mutation status ${ }^{b}$ according to the intake of fresh meat, meat products and fish

Quartile/category of intake

\section{Exposure}

Total fresh meat

Cases

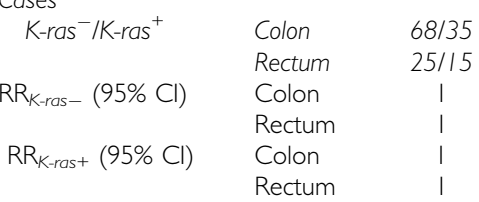

Beef

Cases

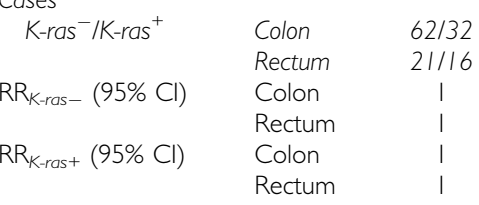

Pork

Cases

$\mathrm{RR}_{\text {Kras- }}(95 \% \mathrm{Cl})$

Colon

Rectum

Colon

$\mathrm{RR}_{\text {kras }}(95 \% \mathrm{Cl})$

Rectum

Colon

Rectum

$85 / 33$
$31 / 12$
1
1
1

Minced meat

Cases

$\begin{array}{cl}\text { K-ras }^{-} / \mathrm{K}_{\text {-ras }}{ }^{+} & \text {Colon } \\ \mathrm{RR}_{\text {K-ras- }}(95 \% \mathrm{Cl}) & \text { Rectum } \\ & \text { Colon } \\ \operatorname{RR}_{\text {K-ras+ }}(95 \% \mathrm{Cl}) & \text { Rectum } \\ & \text { Colon } \\ & \text { Rectum }\end{array}$

$66 / 34$
$19 / 14$
1
1
1
1

Liver

$$
\text { Cases }
$$

K-ras ${ }^{-} / K_{\text {-ras }}{ }^{+}$

$\mathrm{RR}_{\text {Kras- }}(95 \% \mathrm{Cl})$

$\mathrm{RR}_{\text {K-ras+ }}(95 \% \mathrm{Cl})$

Colon

Rectum

Colon

Rectum

Colon

Rectum

Chicken

$$
\text { Cases }
$$

$\begin{array}{clc}\text { K-ras } & \text { ClK-ras } \\ & \text { Colon } & 73 / 42 \\ \mathrm{RR}_{\text {K-ras- }}(95 \% \mathrm{Cl}) & \text { Rectum } & 20 / 13 \\ & \text { Colon } & 1 \\ \mathrm{RR}_{\text {K-ras }}(95 \% \mathrm{Cl}) & \text { Rectum } & 1 \\ & \text { Colon } & 1 \\ & \text { Rectum } & 1\end{array}$

Other meat

\begin{tabular}{|c|c|c|c|}
\hline \multirow[t]{2}{*}{ K-ras ${ }^{-} / K_{\text {-ras }}{ }^{+}$} & Colon & $201 / 101$ & $89 / 43$ \\
\hline & Rectum & $57 / 43$ & $32 / 22$ \\
\hline $2 R_{\text {K-ras- }}(95 \% \mathrm{Cl})$ & Colon & I & $1.16(0.89-1.52)$ \\
\hline & Rectum & I & $0.90(0.63-2.23)$ \\
\hline$R R_{\text {K-ras+ }}(95 \% \mathrm{Cl})$ & Colon & 1 & $1.16(0.79-1.70)$ \\
\hline
\end{tabular}

$$
\text { Cases }
$$

Rectum I $1.24(0.73-2.10)$

$76 / 45$
$25 / 14$
$1.05(0.74-1.49)$
$1.02(0.58-1.80)$
$1.25(0.79-2.00)$
$0.82(0.39-1.72)$

3

$66 / 35$
$18 / 12$
$0.94(0.65-1.36)$
$0.76(0.41-1.44)$
$1.01(0.61-1.66)$
$0.68(0.31-1.47)$

$0.68(0.31-1.47)$
RR $(95 \% \mathrm{Cl})$ for one

$P$ for trend

s.d. increase in intake ${ }^{d}$
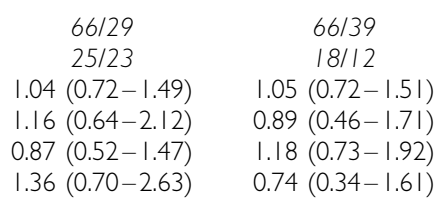

0.61

0.56

0.57

0.1
$0.95(0.84-1.07)$ $0.93(0.75-1.15)$ $0.99(0.85-1.16)$ $0.85(0.67-1.07)$
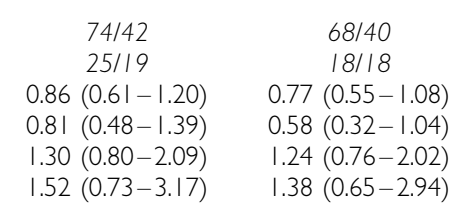
$63 / 29$
$15 / 16$
$0.72(0.51-1.02)$
$0.50(0.26-0.93)$
$0.90(0.53-1.53)$
$1.21(0.56-2.60)$

0.05

0.01

0.68

0.75
$1.08(0.97-1.20)$ $1.02(0.81-1.27)$ $1.04(0.89-1.22)$ $0.84(0.61-1.16)$

$\begin{array}{cc}184 / 98 & 106 / 46 \\ 55 / 41 & 34 / 24 \\ 1 & 1.10(0.86-1.42) \\ 1 & 1.15(0.74-1.79) \\ 1 & 0.92(0.63-1.33) \\ 1 & 1.07(0.63-1.80)\end{array}$

$73 / 27$
$24 / 19$
$.96(0.68-1.36)$
$19(0.64-2.18)$
$64(0.39-1.06)$
$39(0.68-2.85)$

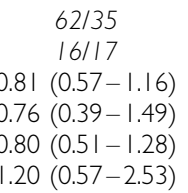

0.68

0.21

0.78

0.66
$0.91(0.80-1.05)$ $0.74(0.57-0.96)$ $0.97(0.82-1.15)$ $1.03(0.82-1.29)$
$1.37(0.97-1.92)$

$1.77(0.99-3.19)$

$1.06(0.64-1.74)$

$1.36(0.68-2.72)$
$0.85(0.58-1.25)$

$1.17(0.62-2.19)$

$1.07(0.65-1.75)$

$0.81(0.37-1.79)$
$0.93(0.82-1.04)$

$1.18(0.99-1.40)$ $0.98(0.83-1.16)$ $0.87(0.68-1.12)$

Meat products ${ }^{\mathrm{e}}$

$$
\text { Cases }
$$

$\begin{array}{llcc}\text { Cases } & & \\ \text { K-ras }^{-} / \text {Kras }^{+} & \text {Colon } & 65 / 40 & 59 / 33 \\ & \text { Rectum } & 28 / 14 & 20 / 9 \\ \text { RR }_{\text {Kras- }}(95 \% \mathrm{Cl}) & \text { Colon } & \mid & 0.91(0.63-1.33) \\ & \text { Rectum } & 1 & 0.71(0.39-1.30)\end{array}$

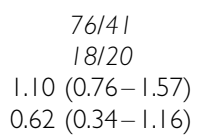

$90 / 30$

$23 / 22$

$1.42(1.00-2.03) \quad 0.03$

$0.84(0.45-1.58)$
0.44

0.54

0.65

0.8

0.44

0.75

0.52

0.75
$1.02(0.91-1.14)$
$1.05(0.89-1.24)$
$1.01(0.85-1.19)$
$0.97(0.74-1.28)$
$0.96(0.84-1.09)$
$1.04(0.85-1.26)$
$0.95(0.79-1.14)$
$0.88(0.68-1.15)$ 
Table 3 (Continued)

Quartile/category of intake

\begin{tabular}{|c|c|c|c|c|c|c|c|}
\hline \multirow[b]{2}{*}{ Exposure } & & \multirow[b]{2}{*}{$P$ for trend } & \multirow[b]{2}{*}{$\begin{array}{l}\text { RR }(95 \% \text { CI) for one } \\
\text { s.d. increase in intake }\end{array}$} \\
\hline & & $I^{c}$ & 2 & 3 & 4 & & \\
\hline \multirow[t]{2}{*}{$\mathrm{RR}_{\text {K-ras+ }}(95 \% \mathrm{Cl})$} & Colon & । & $0.84(0.52-1.37)$ & $1.00(0.63-1.59)$ & $0.77(0.45-1.32)$ & 0.51 & $0.90(0.73-1.11)^{\mathrm{e}}$ \\
\hline & Rectum & I & $0.62(0.26-1.46)$ & $1.26(0.61-2.61)$ & $1.41(0.67-2.99)$ & 0.17 & $1.05(0.86-1.27)^{\mathrm{e}}$ \\
\hline \multicolumn{8}{|l|}{ Fish } \\
\hline \multicolumn{8}{|l|}{ Cases } \\
\hline \multirow[t]{2}{*}{$\mathrm{K}_{\text {-ras }}{ }^{-} / \mathrm{K}_{\text {-ras }}{ }^{+}$} & Colon & $84 / 37$ & $81 / 36$ & $74 / 35$ & $5 / / 36$ & & \\
\hline & Rectum & $25 / 19$ & $20 / 11$ & $24 / 24$ & $20 / 11$ & & \\
\hline \multirow[t]{2}{*}{$\mathrm{RR}_{\mathrm{K} \text {-ras- }}(95 \% \mathrm{Cl})$} & Colon & I & $1.30(0.93-1.81)$ & $0.80(0.57-1.12)$ & $0.87(0.60-1.26)$ & 0.13 & $0.88(0.77-1.02)$ \\
\hline & Rectum & I & $0.97(0.53-1.79)$ & $0.86(0.48-1.52)$ & $1.06(0.58-1.94)$ & 0.99 & $0.97(0.81-1.17)$ \\
\hline \multirow[t]{2}{*}{$\mathrm{RR}_{\text {K-ras }}(95 \% \mathrm{Cl})$} & Colon & I & $1.29(0.79-2.10)$ & $0.87(0.54-1.42)$ & $1.38(0.85-2.25)$ & 0.52 & $1.00(0.85-1.19)$ \\
\hline & Rectum & 1 & $0.76(0.35-1.61)$ & $1.13(0.61-2.07)$ & $0.78(0.37-1.65)$ & 0.84 & $0.86(0.69-1.07)$ \\
\hline
\end{tabular}

a Multivariate adjusted rate ratios (RRs) for age, sex, Quetelet Index (QI), smoking, energy intake and family history of CRC and their $95 \%$ confidence intervals. bWild-type K-ras (Kras $^{-}$): no mutation in the exon I fragment of the gene, mutated K-ras $\left(K_{\text {-ras }}{ }^{+}\right)$: at least one mutation in the exon I fragment of the gene. ${ }^{\mathrm{C}}$ Reference category/quartile of intake. ${ }^{d}$ See for one s.d. of increase based on the intake of the subcohort (Table I). ${ }^{e}$ Rate ratios per increment of I 5 g day ${ }^{-1}$ (s.d. in subcohort), equivalent to one standard sandwich filling.

mutations exist. However, in this study, no associations were found between any of the fresh meat variables and risk of colon or rectal cancer with specific point mutations. This could be due to the expected low content of carcinogens in prepared fresh meat consumed in this cohort, and also to the lack of correlation between meat preparation and the amount of fresh meat consumed. Surprisingly, associations were observed between beef, pork and meat products and cancer with a wild-type $K$-ras gene. Possibly beef, pork and meat products exert their action through another pathway than the $K$-ras signalling route. Although these associations were weak and the inverse association for high consumption of pork cannot readily be explained, they are intriguing and require replication and further study.

It is hypothesised that fat content of meat could influence CRC risk by increasing the excretion of bile acids (Norat et al, 2002). The products of the bile acid excretion may act as tumour promoters by a nonspecific effect that increases cell proliferation in the mucosa layer (Norat et al, 2002). However, total fat intake (Brink et al, 2004) as well as total fresh meat consumption was not associated with overall colon and rectal cancer risk nor with $K$-ras mutation status. In the previous study (Brink et al, 2004), only $\omega-6$ polyunsaturated fat (PUFA) was observed to be associated with specific $K$-ras mutations; however, this type of fat is not predominantly present in meat.

Nitrosamines and their precursors are compounds observed in red and processed meat (Mirvish et al, 2002) or can be endogenously formed (Bingham et al, 2002). Alkylating DNA agents like nitrosamines could generate $O^{6}$-methylguanines and these have been detected in human colonic tissue (Hall et al, 1991). $\mathrm{N}$-nitroso compounds could also induce $\mathrm{G}>\mathrm{A}$ transitions in codons 12 or 13 of the K-ras gene of rat colon carcinomas (Zarbl et al, 1985; Topal, 1988; Jacoby et al, 1992) or in human colonic tissue (Hughes et al, 2001; Bingham et al, 2002). In the current study, no clear association was observed for daily consumption of meat products and overall colon and rectal cancer risk. When the absence or presence of $K$-ras mutations was taken into account, a high intake of meat products was found to be positively associated with colon tumours with a wild-type K-ras gene, as discussed above. In contrast, subgroup analysis of specific point mutations in the K-ras gene showed that high consumption of meat products is positively associated with rectal tumours harbouring a $\mathrm{G}>\mathrm{A}$ transition. Although the association was not statistically significant, this observation is in line with the biological evidence (Zarbl et al, 1985; Topal, 1988; Jacoby et al, 1992; Hughes et al, 2001; Bingham et al, 2002). Why the association in our study is confined to the rectum and not to the colon remains unclear. A plausible explanation for differences in tumour site could be due to the duration of contact with, and the concentration of, the potential dietary carcinogens like nitrosamines. Possibly, the lower transit time of stool in the rectum as compared to the colon leads to an increased exposure time for the rectum. On the other hand, this could be a chance finding, especially concerning the observation that no association was observed between meat products and rectal cancer overall nor with the $K$-ras mutation status Therefore, more aetiological insight in the underlying mechanisms is required to clarify this issue.

We acknowledge that multiple comparisons were performed so that some of the observed associations are chance findings. Therefore, caution is warranted in interpreting the results.

In conclusion, our results indicate that total fresh meat and fish are not associated with colon or rectal cancer risk or with the K-ras mutation status of these cancer types. However, consumption of beef, pork and meat products appear to be associated with colon or rectal tumours with a wild-type $K$-ras gene, suggesting that they may exert their actions in colon or rectal cancer through a pathway independent of a mutation in the K-ras gene.

\section{ACKNOWLEDGEMENTS}

We are indebted to the participants of this study and to Dr M van Engeland, S van de Crommert, J Nelissen, H Brants, M Moll, CWC de Zwart, W van Dijk, K van der Kemp, C Sloot, P Florax and A Pisters for assistance; $T$ van Moergastel for programming; and Professor Dr JW Arends for his participation in the initiation of this study. We also thank the regional cancer registries (IKA, IKL, IKMN, IKN, IKO, IKR, IKST, IKW, IKZ), the Dutch national database of pathology (PALGA), Academisch Ziekenhuis Nijmegen Sint Radboud, Academisch Ziekenhuis Groningen, Rijnland Ziekenhuis, Antoni van Leeuwenhoek Ziekenhuis, Academisch Ziekenhuis Rotterdam, Stichting Laboratorium Pathologie Oost Nederland, Pathologisch Instituut Utrecht, Ziekenhuis Rijnstate Arnhem, Laboratorium Volksgezondheid Leeuwarden, Ziekenhuis Bethesda, Stichting Samenwerkend Ziekenhuizen Oost Groningen, Martini Ziekenhuis Groningen, Samenwerkend Stichting Delftse Ziekenhuizen, Leyenburg Ziekenhuis, Academisch Ziekenhuis Vrije Universiteit, Academisch Medisch Centrum, Sint Franciscus Ziekenhuis, Dr Daniel den Hoed Kliniek, Academisch Ziekenhuis Maastricht, Goudse Ziekenhuizen Stichting Laboratorium, Canisius Wilhelmina Ziekenhuis, Slootervaart Ziekenhuis, Maaslandziekenhuis, Atrium 
Table 4 Adjusted $\mathrm{RR}^{\mathrm{a}}$ for colon and rectal cancer patients with specific point mutations ${ }^{\mathrm{b}}$ in the K-ras oncogene according to the intake of fresh meat, meat products and fish

\section{Quartile/category of intake}

\begin{tabular}{|c|c|c|c|c|c|c|c|}
\hline Exposure & & $I^{c}$ & 2 & 3 & 4 & $\begin{array}{l}P \text { for } \\
\text { trend }\end{array}$ & $\begin{array}{l}\mathrm{RR}(95 \% \mathrm{Cl}) \text { for on } \\
\text { increase in intak }\end{array}$ \\
\hline \multicolumn{8}{|l|}{$\begin{array}{l}\text { Total fresh meat } \\
\text { Cases } \\
\qquad G>A^{+} / G>T^{+}, G>C^{+}\end{array}$} \\
\hline & $\begin{array}{l}\text { Colon } \\
\text { Rectum }\end{array}$ & $\begin{array}{l}16 / 16 \\
11 / 5\end{array}$ & $\begin{array}{l}16 / 12 \\
13 / 12\end{array}$ & $\begin{array}{c}31 / 13 \\
7 / 6\end{array}$ & $\begin{array}{c}19 / 15 \\
3 / 8\end{array}$ & & \\
\hline $\begin{array}{l}\mathrm{RR}_{G>A^{+}}(95 \% \mathrm{Cl}) \\
\mathrm{RR}_{G>T^{+}, G>C^{+}}(95 \% \mathrm{Cl})\end{array}$ & $\begin{array}{l}\text { Colon } \\
\text { Rectum } \\
\text { Colon } \\
\text { Rectum }\end{array}$ & $\begin{array}{l}1 \\
1 \\
1\end{array}$ & $\begin{array}{l}0.98(0.48-1.98) \\
1.11(0.49-2.51) \\
0.75(0.35-1.61) \\
2.44(0.86-6.92)\end{array}$ & $\begin{array}{l}1.81(0.97-3.40) \\
0.62(0.24-1.64) \\
0.83(0.40-1.73) \\
1.01(0.31-3.27)\end{array}$ & $\begin{array}{l}1.11(0.55-2.22) \\
0.28(0.08-1.03) \\
1.00(0.48-2.08) \\
1.19(0.38-3.68)\end{array}$ & $\begin{array}{l}0.34 \\
0.02 \\
0.97 \\
0.62\end{array}$ & $\begin{array}{l}1.02(0.85-1.22) \\
0.71(0.55-0.93) \\
1.01(0.78-1.32) \\
0.94(0.65-1.36)\end{array}$ \\
\hline \multicolumn{8}{|l|}{$\begin{array}{l}\text { Beef } \\
\qquad \text { Cases } \\
\qquad G>A^{+} / G>T^{+}, G>C^{+}\end{array}$} \\
\hline & $\begin{array}{l}\text { Colon } \\
\text { Rectum }\end{array}$ & $\begin{array}{l}16 / 14 \\
7 / 9\end{array}$ & $\begin{array}{l}19 / 7 \\
14 / 8\end{array}$ & $\begin{array}{c}19 / 18 \\
7 / 6\end{array}$ & $\begin{array}{c}28 / 17 \\
5 / 9\end{array}$ & & \\
\hline $\begin{array}{l}\mathrm{RR}_{G>A^{+}}(95 \% \mathrm{Cl}) \\
\mathrm{RR}_{G>T^{+}, G>\mathrm{C}^{+}}(95 \% \mathrm{Cl})\end{array}$ & $\begin{array}{l}\text { Colon } \\
\text { Rectum } \\
\text { Colon } \\
\text { Rectum }\end{array}$ & $\begin{array}{l}1 \\
1 \\
1\end{array}$ & $\begin{array}{l}1.13(0.57-2.26) \\
2.00(0.79-5.06) \\
0.48(0.19-1.19) \\
0.81(0.31-2.17)\end{array}$ & $\begin{array}{l}1.13(0.57-2.21) \\
1.08(0.37-3.11) \\
1.26(0.62-2.58) \\
0.63(0.21-1.87)\end{array}$ & $\begin{array}{l}1.41(0.74-2.66) \\
0.68(0.21-2.26) \\
1.02(0.50-2.08) \\
0.82(0.30-2.21)\end{array}$ & $\begin{array}{l}0.3 \\
0.25 \\
0.47 \\
0.64\end{array}$ & $\begin{array}{l}1.11(0.91-1.36) \\
0.67(0.47-0.95) \\
0.99(0.78-1.26) \\
1.06(0.69-1.61)\end{array}$ \\
\hline
\end{tabular}

Pork

$$
\text { Cases }
$$

$$
G>A^{+} / G>T^{+}, G>C^{+}
$$$$
\mathrm{RR}_{G>A^{+}}(95 \% \mathrm{Cl})
$$$$
\mathrm{RR}_{\mathrm{G}>\mathrm{T}^{+}, \mathrm{G}>\mathrm{C}^{+}}(95 \% \mathrm{Cl})
$$

$$
\begin{aligned}
& \text { Minced meat } \\
& \text { Cases } \\
& \quad G>A^{+} / G>T^{+}, G>C^{+} \\
& \operatorname{RR}_{G>A^{+}}(95 \% \mathrm{Cl}) \\
& \operatorname{RR}_{G>T^{+}, G>C^{+}}(95 \% \mathrm{Cl})
\end{aligned}
$$

Liver

$$
\begin{aligned}
& \text { Cases } \\
& \qquad \rightarrow>A^{+} / G>T^{+}, G>C^{+}
\end{aligned}
$$$$
\mathrm{RR}_{G>A^{+}}(95 \% \mathrm{Cl})
$$$$
\mathrm{RR}_{G>T^{+}, G>C^{+}}(95 \% \mathrm{Cl})
$$

Chicken

$$
\begin{aligned}
& \text { Cases } \\
& \qquad \mathrm{G}>\mathrm{A}^{+} / G>T^{+}, G>C^{+}
\end{aligned}
$$$$
\mathrm{RR}_{\mathrm{G}>\mathrm{A}^{+}}(95 \% \mathrm{Cl})
$$$$
\mathrm{RR}_{\mathrm{G}>T^{+}, \mathrm{G}>\mathrm{C}^{+}}(95 \% \mathrm{Cl})
$$

$20 / 12$
$7 / 7$
1
1
1

$$
\begin{gathered}
15 / 18 \\
11 / 8 \\
0.71(0.36-1.40) \\
1.56(0.61-4.01) \\
1.44(0.69-3.04) \\
1.06(0.39-2.89)
\end{gathered}
$$$$
\begin{aligned}
& 19 / 16 \\
& 9111
\end{aligned}
$$$$
\text { 25/12 }
$$$$
10 / 7
$$$$
1.67(0.60-4.66)
$$$$
1.43(0.68-2.98)
$$$$
1.28(0.69-2.40)
$$$$
\text { I.7| }(0.60-4.90)
$$$$
0.98(0.43-2.22)
$$$$
0.99(0.33-2.97)
$$

$\begin{array}{cc}15 / 13 & \\ 7 / 8 & \\ 0.77(0.38-1.56) & 0.53 \\ 1.23(0.40-3.77) & 0.72 \\ 1.07(0.48-2.41) & 0.88 \\ 1.07(0.37-3.13) & 0.74\end{array}$

$0.86(0.70-1.06)$ $0.92(0.68-1.25)$ $1.10(0.83-1.46)$ $1.06(0.74-1.5 \mid)$
$1.09(0.9|-| .3 \mid)$ $0.86(0.61-1.22)$ $0.89(0.67-1.18)$ $0.88(0.61-1.27)$
Colon

Rectum

Colon

Rectum

Colon

Rectum

$\begin{array}{cc}56 / 36 & 26 / 20 \\ 23 / 18 & 10 / 14 \\ 1 & 0.91(0.55-1.49) \\ 1 & 0.79(0.38-1.65) \\ 1 & 1.12(0.64-1.94) \\ 1 & 1.45(0.69-3.05)\end{array}$

0.7

0.53

0.7

0.32
$1.01(0.82-1.26)$ $0.53(0.3|-0.9|)$ $1.10(0.90-1.36)$ $1.18(0.92-1.50)$
Other meat

$$
\text { Cases }
$$

$$
G>A^{+} / G>T^{+}, G>C^{+}
$$$$
\mathrm{RR}_{\mathrm{G}>\mathrm{A}^{+}}(95 \% \mathrm{Cl})
$$

$\begin{array}{lcc}\text { Colon } & 55 / 42 & 27 / 14 \\ \text { Rectum } & 20 / 22 & 13 / 10 \\ \text { Colon } & 1 & 1.33(0.82-2.17) \\ \text { Rectum } & 1 & 1.57(0.79-3.13)\end{array}$

\section{$21 / 13$}

111110

$0.57(0.29-1.13)$

$1.59(0.61-4.19)$

$0.59(0.27-1.29)$

$1.52(0.55-4.19)$
$0.84(0.46-1.53) \quad 0.78(0.43-1.42) \quad 0.66$

$1.08(0.38-3.07) \quad 0.85(0.29-2.46) \quad 0.52$

$0.74(0.36-.53) \quad 0.81(0.41-1.61) \quad 0.7$

$1.36(0.47-3.91) \quad 0.86(0.29-2.59) \quad 0.65$
$0.94(0.74-1.18)$

$0.88(0.59-1.32)$

$0.95(0.69-1.30)$

$0.80(0.54-1.18)$ 


\begin{tabular}{|c|c|c|c|c|c|c|c|}
\hline \multirow[b]{2}{*}{ Exposure } & \multicolumn{5}{|c|}{ Quartile/category of intake } & \multirow{2}{*}{$\begin{array}{l}P \text { for } \\
\text { trend }\end{array}$} & \multirow{2}{*}{$\begin{array}{l}\text { RR }(95 \% \mathrm{Cl}) \text { for one s.d. } \\
\text { increase in intake }^{d}\end{array}$} \\
\hline & & $I^{c}$ & 2 & 3 & 4 & & \\
\hline $\mathrm{RR}_{G>T^{+}, G>C^{+}}(95 \% \mathrm{Cl})$ & $\begin{array}{l}\text { Colon } \\
\text { Rectum }\end{array}$ & 1 & $\begin{array}{l}0.94(0.50-1.77) \\
1.10(0.50-2.41)\end{array}$ & & & $\begin{array}{l}0.85 \\
0.81\end{array}$ & $\begin{array}{l}0.99(0.76-1.29) \\
0.90(0.63-1.27)\end{array}$ \\
\hline \multicolumn{8}{|l|}{$\begin{array}{l}\text { Meat products } \\
\text { Cases } \\
\qquad G>A^{+} / G>T^{+}, G>C^{+}\end{array}$} \\
\hline & $\begin{array}{l}\text { Colon } \\
\text { Rectum }\end{array}$ & $\begin{array}{l}20 / 16 \\
6 / 7\end{array}$ & $\begin{array}{l}16 / 16 \\
5 / 5\end{array}$ & $\begin{array}{l}24 / 16 \\
11110\end{array}$ & $\begin{array}{l}22 / 8 \\
11110\end{array}$ & & \\
\hline $\begin{array}{l}\mathrm{RR}_{G>\mathrm{A}^{+}}(95 \% \mathrm{Cl}) \\
\mathrm{RR}_{G>T^{+}, G>\mathrm{C}^{+}}(95 \% \mathrm{Cl})\end{array}$ & $\begin{array}{l}\text { Colon } \\
\text { Rectum } \\
\text { Colon } \\
\text { Rectum }\end{array}$ & $\begin{array}{l}1 \\
1 \\
1\end{array}$ & $\begin{array}{l}0.79(0.40-1.55) \\
0.89(0.27-2.99) \\
1.06(0.52-2.17) \\
0.65(0.20-2.16)\end{array}$ & $\begin{array}{l}1.11(0.60-2.08) \\
1.98(0.69-5.62) \\
1.03(0.50-2.11) \\
1.16(0.41-3.24)\end{array}$ & $\begin{array}{l}1.08(0.54-2.16) \\
2.37(0.75-7.51) \\
0.53(0.22-1.28) \\
1.08(0.38-3.05)\end{array}$ & $\begin{array}{l}0.61 \\
0.07 \\
0.2 \\
0.63\end{array}$ & $\begin{array}{l}0.98(0.78-1.23)^{\mathrm{e}} \\
1.14(0.90-1.45)^{\mathrm{e}} \\
0.82(0.55-1.23)^{\mathrm{e}} \\
1.02(0.77-1.35)^{\mathrm{e}}\end{array}$ \\
\hline
\end{tabular}

a Multivariate adjusted rate ratios (RRs) for age, sex, Quetelet Index (QI), smoking, energy intake and family history of CRC and their $95 \%$ confidence intervals. ${ }^{\mathrm{b}}$ The presence of $\mathrm{G}>\mathrm{A}$ transitions $\left(G>A^{+}\right)$or $\mathrm{G}>\mathrm{T}$ or $\mathrm{G}>\mathrm{C}$ transversions $\left(G>T^{+}, G>C^{+}\right)$in the exon I fragment of the K-ras gene. ${ }^{\mathrm{C}}$ Reference category/quartile of intake. ${ }^{\mathrm{d}}$ See for one s.d. of increase based on the intake of the subcohort (Table I). ${ }^{e}$ Rate ratios per increment of $15 \mathrm{~g} \mathrm{day}^{-1}$ (s.d. in subcohort), equivalent to one standard sandwich filling.

Heerlen, Atrium Kerkrade and Brunssum, Microbiologie St Medische Stedendriehoek, Ijsselmeer Ziekenhuizen, Ziekenhuis Centrum Apeldoorn, Isala Klinieken, Elkeriekziekenhuis, Groot Ziekengasthuis, Ziekenhuis Gooi Noord, Medisch Centrum Alkmaar, Regionaal Pathologisch en Cytologisch Laboratorium voor Eemland en Noord-West Veluwe, Diakonesse Ziekenhuis, Sint Antonius Ziekenhuis, Onze Lieve Vrouwe Gasthuis, St Lucas Andreas Ziekenhuis, Pathologisch Anatomisch Laboratorium

\section{REFERENCES}

Augustsson K, Skog K, Jagerstad M, Dickman PW, Steineck G (1999) Dietary heterocyclic amines and cancer of the colon, rectum, bladder, and kidney: a population-based study [see comments]. Lancet 353(9154): $703-707$

Barlow WE, Ichikawa L, Rosner D, Izumi S (1999) Analysis of case - cohort designs. J Clin Epidemiol 52(12): 1165-1172

Bautista D, Obrador A, Moreno V, Cabeza E, Canet R, Benito E, Bosch X, Costa J (1997) Ki-ras mutation modifies the protective effect of dietary monounsaturated fat and calcium on sporadic colorectal cancer. Cancer Epidemiol Biomark Prev 6(1): 57-61

Bingham SA, Hughes R, Cross AJ (2002) Effect of white vs red meat on endogenous $\mathrm{N}$-nitrosation in the human colon and further evidence of a dose response. J Nutr 132(11 Suppl): 3522S-3525S

Bingham SA, Pignatelli B, Pollock JR, Ellul A, Malaveille C, Gross G, Runswick S, Cammings JH, O’Neill IK (1996) Does increased endogenous formation of N-nitroso compounds in the human colon explain the association between red meat and colon cancer? Carcinogenesis 17(3): $515-523$

Bos JL, Fearon ER, Hamilton SR, Verlaan-de Vries M, van Boom JH, van der Eb AJ, Vogelstein B (1987) Prevalence of ras gene mutations in human colorectal cancers. Nature 327(6120): 293-297

Breivik J, Meling GI, Spurkland A, Rognum TO, Gaudernack G (1994) K-ras mutation in colorectal cancer: relations to patient age, sex and tumour location. Br J Cancer 69(2): 367-371

Brink M, De Goeij AF, Weijenberg MP, Roemen GM, Lentjes MH, Pachen MM, Smits KM, de Bruïne AP, Goldbohm RA, van den Brandt PA (2003)
SPALK, Ziekenhuis de Heel, Diakonessenhuis, Rode Kruis Ziekenhuis, Ziekenhuis Bronovo, Laurentius Ziekenhuis Roermond, Pathologisch Anatomisch Laboratorium Dordrecht, Zuiderziekenhuis, Sint Clara Ziekenhuis, Medisch Centrum Haaglanden, St Streeklaboratorium Zeeland, Sint Elisabeth Ziekenhuis, Catharinaziekenhuis, Sint Maartensgasthuis and Spaarne Ziekenhuis for providing the tissue blocks. This work is supported by a grant from the Dutch Cancer Society.
$K$-ras oncogene mutations in sporadic colorectal cancer in The Netherlands Cohort Study. Carcinogenesis 24(4): 703-710

Brink M, Weijenberg MP, de Goeij AF, Schouten LJ, Koedijk FD, Roemen GM, Lentjes MH, de Bruïne AP, Goldbohm RA, van den Brandt PA (2004) Fat and K-ras mutations in sporadic colorectal cancer in The Netherlands Cohort Study. Carcinogenesis 25(9): 1619-1628

Fearon ER, Vogelstein B (1990) A genetic model for colorectal tumorigenesis. Cell 61(5): $759-767$

Gerhardsson de Verdier M, Hagman U, Peters RK, Steineck G, Overvik E (1991) Meat, cooking methods and colorectal cancer: a case-referent study in Stockholm. Int J Cancer 49(4): 520-525

Giovannucci E, Willett WC (1994) Dietary factors and risk of colon cancer. Ann Med 26(6): $443-452$

Goldbohm RA, van den Brandt PA, Brants HA, van't Veer P, Al M, Sturmans F, Hermus RJ (1994a) Validation of a dietary questionnaire used in a large-scale prospective cohort study on diet and cancer. Eur $J$ Clin Nutr 48(4): $253-265$

Goldbohm RA, van den Brandt PA, van't Veer P, Brants HA, Dorant E, Sturmans F, Hermus RJ (1994b) A prospective cohort study on the relation between meat consumption and the risk of colon cancer. Cancer Res 54(3): $718-723$

Hall CN, Badawi AF, O'Connor PJ, Saffhill R (1991) The detection of alkylation damage in the DNA of human gastrointestinal tissues. $\mathrm{Br} J$ Cancer 64(1): 59-63

Hill MJ, Morson BC, Bussey HJ (1978) Aetiology of adenoma - carcinoma sequence in large bowel. Lancet 1(8058): 245-247 
Hughes R, Cross AJ, Pollock JR, Bingham S (2001) Dose-dependent effect of dietary meat on endogenous colonic N-nitrosation. Carcinogenesis 22(1): $199-202$

Jacoby RF, Alexander RJ, Raicht RF, Brasitus TA (1992) K-ras oncogene mutations in rat colon tumors induced by $\mathrm{N}$-methyl- $\mathrm{N}$-nitrosourea. Carcinogenesis 13(1): 45-49

Kampman E, Slattery ML, Bigler J, Leppert M, Samowitz W, Caan BJ, Potter JD (1999) Meat consumption, genetic susceptibility, and colon cancer risk: a United States multicenter case-control study. Cancer Epidemiol Biomark Prev 8(1): 15-24

Kampman E, Voskuil DW, van Kraats AA, Balder HF, van Muyen GN, Goldbohm RA, van't Veer P (2000) Animal products and K-ras codon 12 and 13 mutations in colon carcinomas. Carcinogenesis 21(2): 307-309

Martinez ME, Maltzman T, Marshall JR, Einspahr J, Reid ME, Sampliner R, Ahnen DJ, Hamilton SR, Alberts DS (1999) Risk factors for Ki-ras protooncogene mutation in sporadic colorectal adenomas. Cancer Res 59(20): $5181-5185$

Martinez-Garza SG, Nunez-Salazar A, Calderon-Garciduenas AL, BosquesPadilla FJ, Niderhauser-Garcia A, Barrera-Saldana HA (1999) Frequency and clinicopathology associations of $\mathrm{K}$-ras mutations in colorectal cancer in a northeast Mexican population. Dig Dis 17(4): 225-229

Mirvish SS, Haorah J, Zhou L, Clapper ML, Harrison KL, Povey AC (2002) Total N-nitroso compounds and their precursors in hot dogs and in the gastrointestinal tract and feces of rats and mice: possible etiologic agents for colon cancer. J Nutr 132(11 Suppl): 3526S-3529S

Nevo table (1986) Dutch Food Composition Table 1986-1987. The Hague: het Voedingscentrum

Norat T, Lukanova A, Ferrari P, Riboli E (2002) Meat consumption and colorectal cancer risk: dose-response meta-analysis of epidemiological studies. Int J Cancer 98(2): $241-256$

O'Brien H, Matthew JA, Gee JM, Watson M, Rhodes M, Speakman CT, Stebbings WS, Kennedy HJ, Johnson IT (2000) K-ras mutations, rectal crypt cells proliferation, and meat consumption in patients with leftsided colorectal carcinoma. Eur J Cancer Prev 9(1): $41-47$

Potter JD (1996) Nutrition and colorectal cancer. Cancer Causes Control 7(1): $127-146$

Schoenfeld D (1982) Partial residuals for the proportional hazards regression model. Biometrika 69: 239-241
Schouten LJ, Jager JJ, van den Brandt PA (1993) Quality of cancer registry data: a comparison of data provided by clinicians with those of registration personnel. Br J Cancer 68(5): $974-977$

Schouten LJ, Straatman H, Kiemeney LA, Gimbrere CH, Verbeek AL (1994) The capture-recapture method for estimation of cancer registry completeness: a useful tool? Int J Epidemiol 23(6): 1111-1116

Slattery ML, Curtin K, Anderson K, Ma KN, Edwards S, Leppert M, Potter J, Schaffer D, Samowitz WS (2000) Associations between dietary intake and Ki-ras mutations in colon tumors: a population-based study. Cancer Res 60(24): 6935-6941

Topal MD (1988) DNA repair, oncogenes and carcinogenesis. Carcinogenesis 9(5): $691-696$

Urosevic N, Krtolica K, Skaro-Milic A, Knezevic-Usaj S, Dujic A (1993) Prevalence of G-to-T transversions among K-ras oncogene mutations in human colorectal tumors in Yugoslavia. Int J Cancer 54(2): 249-254

van den Brandt PA, Goldbohm RA, van't Veer P, Volovics A, Hermus RJ, Sturmans F (1990a) A large-scale prospective cohort study on diet and cancer in The Netherlands. J Clin Epidemiol 43(3): 285-295

van den Brandt PA, Schouten LJ, Goldbohm RA, Dorant E, Hunen PM (1990b) Development of a record linkage protocol for use in the Dutch Cancer Registry for Epidemiological Research. Int J Epidemiol 19(3): $553-558$

van der Sanden GA, Coebergh JW, Schouten LJ, Visser O, van Leeuwen FE (1995) Cancer incidence in The Netherlands in 1989 and 1990: first results of the nationwide Netherlands cancer registry. Coordinating Committee for Regional Cancer Registries. Eur J Cancer 31A(11): $1822-1829$

Vineis P, McMichael A (1996) Interplay between heterocyclic amines in cooked meat and metabolic phenotype in the etiology of colon cancer. Cancer Causes Control 7(4): 479-486

Vogelstein B, Fearon ER, Hamilton SR, Kern SE, Preisinger AC, Leppert M, Nakamura Y, White R, Smits AM, Bos JL (1988) Genetic alterations during colorectal-tumor development. N Engl J Med 319(9): 525-532

Voskuil DW (1999) Diet-gene interactions in sporadic and hereditary colorectal carcinogenesis; epidemiological perspectives. Thesis (in Dutch)

Zarbl H, Sukumar S, Arthur AV, Martin-Zanca D, Barbacid M (1985) Direct mutagenesis of Ha-ras-1 oncogenes by $N$-nitroso- $N$-methylurea during initiation of mammary carcinogenesis in rats. Nature 315(6018): $382-385$ 